\title{
Spretnosti pri upravljanju, izvajanju in koordinaciji osebne asistence in implementacija zakona o osebni asistenci v socialnem varstvu: učenje po dobrih vzorih
}

Seminar s tem imenom je potekal 27. maja 2021 na Fakulteti za socialno delo prek videokonferenčne aplikacije Zoom, vodile pa so ga prof. dr. Darja Zaviršek, Elena Pečarič in Katrin Modic. Usposabljanje s področja osebne asistence se je začelo z pojasnitvijo osnovnih pojmov in konceptov. Opredelili smo razliko med samostojnim in neodvisnim življenjem ter definirali, kaj je osebna asistenca in kaj omogoča uporabniku, spoznali smo načela neodvisnega življenja, govorili o ovirah za neodvisno življenje in rabi jezika oz. primerni terminologiji v kontekstu neodvisnega življenja, ki ga omogoča Zakon o osebni asistenci.

V nadaljevanju smo si ogledali kratek odlomek slovenskega dokumentarnega filma živi $M$, v katerem je predstavljen zaposlitveni pogovor za delovno mesto osebne asistentke, ki ga vodi uporabnica osebne asistence Martina Piskač. Na podlagi videnega smo se pogovarjali o iskanju in izbiri osebnih asistentov ter o vlogi uporabnika, ki je neformalni delodajalec, s pravicami in odgovornostmi. Poudarili smo, da je izobraževanje oziroma usposabljanje uporabnikov in osebnih asistentov eden izmed najboljših načinov spodbujanja neodvisnega življenja in hkrati preprečevanja nesporazumov in zapletov v odnosu med uporabnikom osebne asistence, osebnim asistentom in izvajalcem osebne asistence.

Potem smo si ogledali odlomek iz televizijske oddaje Prisluhnimo tišini "Prevetritev osebne asistence in sporne čudežne kapljice», ki je bila predvajana 27. februarja 2021 na Prvem programu RTV SLO. Začeli smo razpravljati o izzivih izvajanja osebne asistence, kaj osebna asistenca je in kaj ni ter kako bi jo v kontekstu odlomka lahko še izboljšali. Srečanje smo sklenili z razpravo in konkretnimi vprašanji o izvajanju in organizaciji osebne asistence.

Seminarja so se udeležili koordinatorji osebne asistence, strokovne vodje, usklajevalci in uporabniki osebne asistence ter drugi raziskovalci področja osebne asistence. Celoten seminar je potekal interaktivno, z diskusijami, predstavljanjem dobrih praks in delom v skupinah. Posebna dragocenost seminarja je bila, da sta ga sovodili osebi, ki osebno asistenco poznata iz prve roke. Elena Pečarič je pionirka osebne asistence v Sloveniji, Katrin Modic pa osebno asistenco uporablja že več kot petnajst let tudi sama (enako kot Elena Pečarič).

Na seminarju smo se med drugim pogovarjali o različnih spretnostih in pristopih, ki lahko uporabnike osebne asistence spodbudijo k večji neodvisno- 
sti. ${ }^{1} \mathrm{~K}$ doseganju tega cilja odločilno pripomorejo: poglobljeno osnovno usposabljanje za uporabnike osebne asistence in dodatna usposabljanja po izbiri izvajalca osebne asistence, redno spremljanje načina izvajanja osebne asistence (spremljajo ga strokovni vodja, usklajevalci osebne asistence in koordinatorji osebne asistence na centru za socialno delo), podpora vrstniške skupine, ki je lahko formalna ali neformalna, in zgled. Prav zgled me je še posebej pritegnil, saj je morda najbolj spregledan, a izjemno pomemben pristop.

Vsebina seminarja je sprožila vprašanje vzorništva in učenja po dobrih zgledih pri izvajanju in organiziranju osebne asistence.

Osebe s priznano pravico do osebne asistence po Zakonu o osebni asistenci se v marsičem razlikujejo, vendar jih gotovo povezuje to, da si lahko (najverjetneje) prvič v življenju s pomočjo osebne asistence uredijo življenje po svojih merilih in željah. To zanje pomeni možnost uresničenja sanj in hkrati velik izziv. Njihovo dosedanje življenje je bilo sosledje prilagajanj drugim osebam, ki so jim prostovoljno ali poklicno pomagale. Kaj pa zdaj? Kaj in kako delati z vso svobodo, ki jo ima oseba s pravico do osebne asistence? Pri tem posamezniki pogosto niti ne slutijo, koliko možnosti izbire in načinov življenja imajo, prav tako pa velikokrat ne vedo, kako izbrani način življenja uresničiti. Vloga vzornika je pri tem ključna. Vzornik s svojim zgledom kaže na različne možnosti in načine življenja ter organiziranja osebne asistence $s$ tem, ko živi svojo različico neodvisnega življenja. Vzornik opogumlja in dokazuje, kaj vse je mogoče doseči z uporabo storitev osebne asistence in kako si jo je mogoče optimalno organizirati, da s tem ( $\mathrm{v}$ okviru delovnopravne zakonodaje) zadovoljimo svoje potrebe in uresničimo svoje sanje.

Pomembno se je zavedati, da je lahko vzornik tudi mentor, ki novega uporabnika osebne asistence vodi skozi proces organizacije osebne asistence in mu zaupa svoje izkušnje in dobre prakse. Poudarek naj bo seveda na praktičnosti in osebni izkušnji. Najboljši vzornik je tisti, ki sam uspešno uporablja storitve osebne asistence. S tega vidika je smiselno spodbujanje zaposlovanja uporabnikov osebne asistence na delovna mesta strokovnih vodij in usklajevalcev osebne asistence ter vključevanje drugih zunanjih sodelavcev in prostovoljcev, ki so uporabniki osebne asistence.

Vsak vzornik oziroma mentor ima odgovornost do posameznika, kateremu svetuje, kakor tudi do Zakona o osebni asistenci in družbi kot taki. Sam naj živi in pri drugih naj spodbuja splošne humanistične vrednote modrosti, pravičnosti, poguma in zmernosti (stoiške vrednote) in seveda dialoga, nenasilja, razumnosti, spoštovanja. Širi naj ponižnost in zavedanje, da je načinov življenja veliko in da obstaja tudi več načinov izvajanja in organizacije osebne asistence, ki so lahko enakovredni. Sebe naj ne predstavlja kot najboljši in edini pravilni model izvajanja osebne asistence, kot voditelja ali kot rešitev za vse izzive izvajanja osebne asistence. Svoj način organizacije osebne asistence naj ponudi prosto in dobronamerno z zavedanjem, da ni univerzalno aplikativen.

Besede » neodvisnost « ne gre jemati dobesedno, saj smo ljudje skupnostna bitja, ki v samem temelju že od rojstva za razvoj potrebujemo druge, od katerih smo odvisni. Skupnost, ki jo v odraslosti soustvarjamo in nam omogoča varnejše in bolj zdravo življenje, prav tako temelji na določeni stopnji soodvisnosti in sodelovanja. 
Svoj način organizacije osebne asistence lahko vzornik analizira sam in ga $v$ obliki svetovanja in praktičnega zgleda posreduje drugim, lahko pa sam uporabnik izvede aktivni proces učenja po dobrem vzoru, ${ }^{2}$ ki je v tem primeru odlično izvajanje in organizacija osebne asistence.

Tema vzorništva in učenja po dobrih vzorih, ki dosegajo odličnost, je ključna za uspešno izvajanje in organizacijo osebne asistence na vseh ravneh. Smiselno bi bilo tudi, da bi dobre prakse v prihodnje še bolj usmerjale razvoj Zakona o osebni asistenci.

\section{Mirjana Borenović}


